\title{
Fractional Laser Photothermolysis in the Treatment of Skin Defects: Possibilities and Effectiveness (Review)
}

DO1. 10, $17691 / \mathrm{stm} 2016,8.2 .14$

Received April 5, 2016

M.M. Karabut, Junior Researcher, Laboratory for the Study of the Optical Structure of Biotissue,

Institute of Biomedical Technologies;

N.D. Gladkova, MD, DSc, Professor, Vice Director for Science, Institute of Biomedical Technologies;

F.I. Feldchtein, PhD, Leading Researcher, Institute of Biomedical Technologies;

Consultant for Biophotonics (USA)

Nizhny Novgorod State Medical Academy, 10/1 Minin and Pozharsky Square, Nizhny Novgorod, 603005,

Russian Federation

For skin defect treatment and rejuvenation the ablative laser skin resurfacing with a $\mathrm{CO}_{2}$ laser is widely applied in cosmetology and dermatology. However this treatment can result in the risk of undesirable side effects and requires a long-term recovery after the procedure. When non-ablative laser skin rejuvenation is used as an alternative, the level of safety is increased, however the efficacy of the procedure is considerably reduced.

The use of fractional laser photothermolysis is a particularly important step in the development of laser technology for cosmetology and dermatology. Due to the creation of only microscopic areas of thermal damage under the laser exposure, this method results in safe, quick healing and complete recovery of the skin without any undesirable side effects. The review presented here illustrate the high efficacy of the application of both ablative and non-ablative fractional laser photothermolysis for wrinkles reduction, for general improvement of the skin appearance, for the abnormal pigmentation treatment, and the removal or appearance improvement of atrophic scars from acne as well as in areas of skin stretching (striae).

Key words: laser technologies in cosmetology; ablative and non-ablative laser exposure; fractional laser photothermolysis.

The important task of cosmetology and dermatology is skin rejuvenation as well as removal and correction of different aesthetic problems or skin defects such as post-operative scars, acne scars, wrinkles, pigmentation disorders etc. [1]. The different origins of these defects lead to a variety of approaches to their treatment.

\section{Skin defects and their causes}

A skin scar is a newly formed connective tissue which can occur at any site of deep skin damage accompanied by the destruction of the dermis, for example, as a result of inflammatory processes such as acne. The formation of scar tissue has several stages. It develops from granulation tissue which later turns into connective tissue structures, with the scar changing the general skin topography. The dermis loses elastic fibers, while coarse collagen fibers grow in their place and the blood and lymphatic vessels become deformed and significantly reduced in number [2].

Skin scars can be divided into four types: normotrophic, atrophic, hypertrophic, and keloid. The last three are pathological forms. Atrophic scars are formed at sites of skin stretching or inflammatory processes (acne, chickenpox, shingles etc.), and sometimes they can occur after the surgical removal of warts and papillomas. These scars appear as pale indentations with reduced sensitivity. The skin on their surface is thinned because the inflammation causes the destruction of collagen and atrophy of the dermis. The typical appearance of these scars results from the thinning of the epidermis and the lack of collagen and elastin fibers [3].

The post-acne scars are atrophic. The variety of

For contacts: Maria M. Karabut, e-mail: maria.karabut@gmail.com 
post-acne scars appears as different clinical and morphological features that should be taken into account when therapy is being planned. The scars can be narrow, wide, deep or superficial, furrowed, pit-shaped, crater-shaped, saucer-shaped, wavy etc. Based on clinical-morphological manifestations and prevalence, but independently of their individual morphology four degrees of post-acne scar severity can be identified. This quality classification is based on an evaluation of the degree of scar severity and on the impact on the patient's health [4].

Striae are considered some of the most significant skin defects, being atrophic scars in the form of differently colored (from red-bluish to almost white) stripe-like changes of the skin. The main cause is the long term hyperextension of skin fibers, leading to tears in the elastic and collagen fibers, meaning that healthy skin is replaced by the scar tissue. Histologically in the acute stage of formation there is an inflammatory, mainly lymphocytic infiltration around the vessels, while in the chronic stage there is a thinning of the epidermis and of the dermis, a reduction in the number of elastic fibers as well as a homogenization and thinning of the collagen fibers [3, 5].

Skin aging. There are two main types of skin aging: internal (chronological) or external (photoaging). Each of them has its clinical-morphological peculiarities. Aging skin that has not been exposed to the sunlight for a long time is characterized by thinning, reduced elasticity and resilience, paleness and the presence of thin surface (mimic) wrinkles [6]. The main processes in this case are a flattening of the interface between the epidermis and dermis, the disappearance of dermal papillae, a reduced regeneration rate of the epidermis, a reduced number of melanocytes and Langerhans cells in the epidermis, atrophy of the dermis, and a reduced number of fibroblasts, mast cells and blood vessels in the skin. Thus, with aging, the epidermis starts thinning while the number of cell layers remains the same, while hypo- and hyper-pigmentation may also occur there. The main reason for the changes in the dermis in the case of chronological aging is an increased synthesis of type I collagen and a reduced production of elastic fibers and their fragmentation [7].

In photoaging which can be observed before the manifestation of the signs of chronological aging, the skin thickens, becomes drier, forms deep wrinkles, and foci of pigmentation [8]. Melanocytes under exposure to the sun do not undergo any structural changes, however, their number in the basal layer of the epidermis and their size increase. As a result of the melanocyte proliferation pigment spots appear on the skin. The changes in the dermis in photoaging are caused by fibroblasts being damaged by UV-rays reducing their synthesis of collagen and increasing synthesis of the changed elastic fibers (in internal aging collagen is more stable and resistant to destruction). A considerable aggregation of changed elastic fibers leads both to a loss of skin elasticity and causes the corresponding changes in the appearance of the skin: a yellowish color, a coarse, rough surface, and the formation of small nodules. This state has been termed solar (actinic) elastosis [9-13].

Wrinkles and dryness of the skin are the most frequent clinical signs of internal aging and photoaging. Skin dryness (xerosis) is histologically characterized by an increased density of the stratum corneum and an increased thickness of the granular layer of the epidermis [14].

The wrinkles are folds and grooves of different sizes that appear on the skin surface as a result of the loss or of insufficient production of certain substances (collagen, elastin, hyaluronic acid) and by exposure to different physical agents. Histologically wrinkles are characterized by a degradation of the collagen and elastic fibers as well as a reduction in the number of septa in the subcutaneous adipose tissue.

Depending on the causes of their occurrence one can define two types of wrinkle: mimic and age-related ones. The first appear as a result of active contraction of the mimic muscles, the intensity of which depends on the individual's particular behavior. The formation of age wrinkles is caused by the natural processes of aging, accompanied by slower cell division and synthesis, a loss of moisture and a reduced resilience and elasticity of the skin, as well as by the sagging of the skin that occurs over the course of time. At the same time the process of photoaging contributes to the preservation and deepening of the wrinkles [6].

Pigmentation disorders. Pigmentation disorders of the skin (dyschromia, melasma or melanosis) is a serious cosmetic defect that may sometimes be psychosocially harmful. There is no generally accepted classification of pigment formation types, but they can be grouped according to various criteria: their origin primary (innate or acquired) and secondary (postinfection or post-inflammatory); prevalence - localized or generalized; and according to their intensity of coloration - hyper- or hypochromic. Histologically these states are characterized by an increase or decrease in the number of melanocytes in the basal layer of the epidermis. There are various clinical disorders involving damaged melanoformation ranging from increased color intensity, called hypermelanosis, to decreased color intensity — hypomelanosis [15-17].

\section{Laser technology in cosmetology}

Laser technology plays a significant role in the treatment of different cosmetic diseases. The most attractive feature of the application of laser radiation is the ability to concentrate its effect on a limited area, thereby influencing only on specific structures and tissue layers. Furthermore, if necessary, the extent and nature of the influence on the tissues can be changed 
by variation of the optical fluence and the spatial parameters of the radiation. Thus, laser devices allow us to exert accurate control over the temporal and spatial distribution of the energy and power of the radiation for the effective activation of thermal, mechanical or photochemical processes in the tissues [18]. These unique properties of laser radiation have led to the wide application of lasers in surgery, therapy and the diagnosis of skin defects.

Laser technologies are traditionally divided into two types: ablative and non-ablative [19, 20].

Laser ablation involves the eradication of the living tissue directly exposed to the laser radiation. The mechanism and parameters of ablation are determined by the properties of the tissue, the characteristics of the radiation (wavelength, continuous or pulsed radiation, the laser power, the pulse energy, the total absorbed energy etc.) and the coefficient of absorption of the radiation in the specific type of tissue or its individual components [21].

For ablative methods we use $\mathrm{CO}_{2}(\lambda=10,600 \mathrm{~nm})$ and erbium lasers $(\lambda=2,940 \mathrm{~nm})$. As radiation with these wavelengths is readily absorbed by water, it is effective even with the small amount of water (10-15\%) contained in the epidermis [22].

Multiple studies have shown that ablative treatment with $\mathrm{CO}_{2}$ lasers for skin rejuvenation, the removal of scars, age pigmentation, the symptoms of visible photoaging (in conventional laser treatment) can give good and predictable results [23-25]. However this treatment is associated with considerable side effects requiring long-term recovery, erythema (lasts typically 4.5-9.0 months), infections from various sources, temporal and permanent dyschromia (hyper- and hypopigmentation), and scarring. The problem of hypopigmentation can be especially problematic, as it may occur up to 1 year after the treatment and be irreversible [26]. To prevent this requires a reduction in the length and number of procedures, which in its turn may lead to poor clinical results [27, 28].

Erbium lasers have been used as an alternative to carbon dioxide lasers for ablative treatment. In this case, recovery is quicker, but this type of radiation has a smaller depth of optical penetration and, correspondingly, results in a smaller area of ablation and coagulation compared to the $\mathrm{CO}_{2}$ lasers, so the procedure is less effective [29-31]. It should be noted that the depth of coagulation in laser exposure is determined by the energy density and the pulse duration [19].

Such non-ablative lasers are used as an alternative to remove surface wrinkles and atrophic scars. When they are applied, the skin is thermally damaged but without any mechanical destruction. Its recovery after nonablative exposure takes less time, but the treatment is less effective even when several such procedures are used $[1,32]$.

The wavelength of the erbium lasers used for non- ablative methods ranges from $1,400 \mathrm{~nm}$ to $1,550 \mathrm{~nm}$. As this radiation is less well absorbed by water, it can penetrate deeply and be absorbed in the dermis. Since it is simultaneously possible to cool the surface of the epidermis, this minimizes the risk of it being damaged and of further consequences [20,33].

\section{Fractional laser photothermolysis}

The need to develop a treatment that is minimally invasive and has fewer side effects yet is highly effective for cosmetic tasks has existed for many years.

In 2004 Manstein et al. [34] developed a new technology of skin rejuvenation and treatment called fractional photothermolysis (FP). It involves the creation of non-contiguous microthermal zones (MTZs), where the damage is restricted in size, surrounded by areas of undamaged tissue. Due to the preservation of these zones of undamaged tissue the integrity of the epithelium can recover quickly. This considerably reduces the recovery time [34, 35].

The authors presented the results of the fractional effect on the skin of the forearm and on periorbital wrinkles using a prototype of the FP device with a wavelength of $1,500 \mathrm{~nm}$. Three months after treatment, $34 \%$ of the patients showed a significant reduction or smoothing of the periorbital wrinkles while $47 \%$ had moderate enhancement of the skin texture of the forearm. The depth of the MTZs that formed was 300$400 \mu \mathrm{m}$, their diameter was $100 \mu \mathrm{m}$ and the distance between them was upwards of $250 \mu \mathrm{m}$ [34]. It should be noted that the depth and the diameter of the MTZs are determined by the energy of a laser ray and can be adjusted depending on the clinical task [36]. The laser devices widely used in FP of the skin and patterns are described in paper [20].

Mechanisms of fractional laser photothermolysis. The scientific concept on which FP is based relies on the use of microscopic beams of focused light which cause small foci of tissue damage [37]. However the biological mechanisms leading to the complete recovery of the tissue without leaving any scars, and practically without side effects, are somewhat unclear [1].

It is believed that the controlled temperature stress of the epidermis and the dermis during laser damage stimulate the repair and recovery of the skin, activating re-epithelization and a collagen remodeling [38]. It is considered that neocollagenesis is the reason for the long-term enhancement manifested as an increased density of the skin and a smoothing of the wrinkles. Heating of the skin by the laser radiation causes denaturation of collagen, that is, a destruction of the hydrogen bonds in the tertiary helical structure of the collagen fibers and the subsequent formation of random spirals. As soon as such denaturation takes place in a sufficient number of collagen fibers the skin is immediately tightened [27]. 
It is known that when tissue is heated, heat shock proteins (HSP) are activated. Probably this is one of the first basic changes occurring at a molecular level, in addition to changes in the regulation of other molecules, such as transforming growth factor $\beta$ (TGF- $\beta$ ), matrix metalloproteinase, hyaluronate synthase, hyaluronidase and hyaluronic acid [39-43].

HSPs are stress proteins that are activated in all types of cells exposed to heating or to other types of physical and chemical exposure. They enhance the capacity of the cells to overcome the accumulation of damaged (misfolded) proteins, at the same time, simplifying their refolding (repeated folding of the polypeptide chain into the normal spatial structure) or taking part in the synthesis of new proteins to replace the damaged ones. Thus, HSPs are involved in the fundamental processes of cell repair and of wound recovery $[44,45]$. It has been shown that laser exposure enhances the expression of HSP70 in the epidermis around the MTZ damage (in 2-48 $\mathrm{h}$ after the procedure) and in the structures of the dermis, in particular, around blood vessels, hair follicles and sebaceous glands [46]. It is of interest that in nonablative fractional treatment using erbium lasers the maximum level of expression of this protein was lower and was reached later than using ablative $\mathrm{CO}_{2}$ lasers $[47,48]$.

It is known that in the granulation tissue of a recovering wound, type III collagen dominates [49]. However, during recovery, more of the rigid type I collagen accumulates while the amount of type III collagen falls [50]. It was revealed that the expression of HSP47 which mainly participates in the process of synthesis and transportation of pro-a1(I)- and proa2(I)-chains of procollagen I, increases by days 4-7 after laser treatment and then remains constant for 3 months, contributing to the increased accumulation of procollagen and collagen of types I and III [38, 40, 51, 52]. In their study Helbig et al. [38] shows that up to day 14 there is a partial or complete (depending on the level of the applied energy) filling of the MTZs with newly synthesized condensed procollagen III.

Some studies have shown the induction or activation of growth factor TGF- $\beta$ in various types of nonablative laser treatments within 2-14 day of exposure $[39,52]$. It should be noted that such growth factors contribute to the synthesis of matrix components such as fibronectin and collagen, and to the transformation of myofibroblasts, as well as to immunomodulation, to angiogenesis and to the response to heat shock [53-56].

Moreover one of the most important types of enzyme catalyzing the first stage of collagen cleavage is the matrix metalloproteinases (MMPs) the level of which increases in the first three days after the procedure, reaching a maximum up to day 7 but then falling again over the following weeks. The MMP level shows the same dynamics as the degradation of partially cleaved collagen and other proteins of the matrix such as proteoglycans and elastin [52]. There is evidence that MMPs are involved not only in the cleavage, but also in the remodeling of newly synthesized collagen, which happens during the late stages of wound recovery. A different study [57] showed that the level of some MMPs increases slowly, reaching an initial maximum by day 14 after treatment but with a further slight increase by day 28 after the treatment.

Histological studies of the skin after non-ablative FP have shown that immediately after the exposure there is necrosis of the connective tissue and of the epithelium. Despite this, the stratum corneum remains intact. Quick re-epithelization (during the first $24 \mathrm{~h}$ ) occurs due to the migration of keratinocytes and the displacement of damaged epidermal components to the periphery of the thermally affected area. Furthermore, directly after the exposure, there are morphological changes, in the MTZ area in the cells of the basal layer, and that these are connected with their transition to become migrating cells, capable of moving to the area of exposure where they contribute to the quick re-epithelization $[34,37,46]$. Complete recovery of the tissue occurs by day 30 after the exposure [46]. By 3 months there are no detectable damage traces or undesirable side effects [34].

Other studies have also shown that the damaged material of the dermis, including the so-called microscopic epidermal necrotic residues move into the epidermis and are finally eliminated through the stratum corneum [58].

The effects of FP on epidermal pigments are of special interest because some of the currently used non-ablative laser systems working in the infrared spectrum lead to a decrease in the accumulation of pigment in the epidermis but not to its complete removal [59]. Remember that conventional ablative laser resurfacing completely removes the basal layer containing the melanocytes, so it can lead to irreversible hypopigmentation of the skin [37]. One of the most important advantages of non-ablative FP is the reduction of side effects to a minimum in patients with dark skin coloration, by minimizing damage to the epidermis [60]. Manstein et al. [34] showed minimal changes in the pigmentation after FP that resulted in MTZs of low and medium density in patients with dark skin. A histological study has shown that there is a well-controlled mechanism of melanin redistribution using microscopic epidermal necrotic residues as a means of transport. Further studies of this aspect of FP have resulted in the development of new methods of treatment of conditions characterized by pigment damage [61-63].

Taking into account the mechanism of removal of the damaged tissue remains via the epidermis, and further recovery of the damaged zones, the authors [64] suggested that FP can provide a unique therapeutic effect on skin improvement in a number of diseases or in the presence of some types of skin defects.

At present both ablative and non-ablative FP are 
used. Their efficacy for different clinical tasks had been demonstrated in a number of studies [65-69].

Non-ablative FP is an effective method of smoothing wrinkles, skin lifting (tightening), general enhancement of the state of the skin, and in the treatment of pigmentation disorders and atrophic scars. This method is the best to use when a noticeable result is required but without requiring intensive exposure or a long recovery period [37].

Bencicin et al. [70] it was shown that when nonablative FP with an erbium laser having a wavelength $1,540 \mathrm{~nm}$ was used for post-acne scars treatment, their degree of severity was reduced. By 6 months after the treatment end there was a considerable improvement in $98 \%$ of the patients with second degree severity and in $83 \%$ of the patients with third degree severity of scars.

Non-ablative FP is widely used for treating various types of pigmentation abnormalities of the skin associated with the insufficient or excessive synthesis of melanin. A statistically significant difference has been demonstrated between control and experimental groups in treating spontaneous hypomelanosis (appearance of multiple de-pigmented small spots on the skin) with an erbium laser with a wavelength of $1,550 \mathrm{~nm}$. After two procedures there was a statistically significant difference from the control group. At the same time a recovery of the skin complexion was registered at every follow-up visit (every 4 weeks). Obviously, such laser treatment stimulates the production of melanin and so contributes to its recovery to its normal value [71]. However in study [72] the treatment did not result in a significant improvement in the state of melasma (excessive amounts of melanin in the skin) when using non-ablative FP with the same laser. The amount of subjective enhancement evaluated by the patients 12 months after the end of the treatment in the control and experimental groups did not differ. By contrast, study [73] showed that there were changes in the state of the skin at 1,2, and 3 months after non-ablative treatment with an erbium laser having a wave length of $1,410 \mathrm{~nm}$. It was noted that the index of melanin 1 month after the treatment did not change, but it had fallen significantly compared to the initial level by 2 and 3 months. At the same time the melasma area and severity index (MASI) had fallen considerably by 1 month and remained at the same level at 2 and 3 months after the treatment.

It is important to understand how the effects obtained in non-ablative FP change over the course of time after the procedure. Liu et al. [74] evaluated the short-term and long-term effects of fractional treatment with an erbium laser at the wave length of $1,550 \mathrm{~nm}$ for treating facial acne. It was shown that in the short-term followup, 1 month after four procedures, the IGA (Investigator Global Assessment) parameter was significantly improved, namely it fell from 3.12 to 1.31 . The extent of acne had fallen (to $67.7 \%$ ) by one month after the treatment. In the long-term follow-up (from 6 months to
2 years) the average reduction of the acne was between 72 and $75 \%$. A number of studies $[75,76]$ have indicated not only a considerable improvement in skin defects but also a general recovery of the surrounding tissues after non-ablative FP.

In study [76] along with a significant improvement of the appearance of striae by 8 weeks after the treatment with non-ablative FP there was a considerable increase in the thickness of the epidermis as well as a recovery of the tissue elasticity.

Studies [75] showed the effect of non-ablative fractional laser treatment of wrinkles on the neck and forehead by 3 months after treatment. Their smoothing, as well a significant increase in thickness and resilience of the skin in general, was registered.

Some studies have evaluated the frequency and duration of the occurrence of the side effects of nonablative treatment. So, Lee et al. [77] showed that the use of an erbium laser with a wavelength of $1,550 \mathrm{~nm}$ and a thulium laser with a wavelength of $1,927 \mathrm{~nm}$ for non-ablative fractional exposure resulted in undesirable side effects in only $5 \%$ of patients after the procedure. Those side effects mainly involved erythema (1.8\%), post-inflammatory hyperpigmentation - the formation of dark spots at the place of the inflammatory process or skin damage, involved in the cosmetic procedures $(1.1 \%)$ and an increase in melasma $(0.9 \%)$; while the rarest side-effects were: herpes simplex $(0.6 \%)$ and acne $(0.2 \%)$. No long-term side effects were registered.

As undesirable side effects one can also include moderate or short-time pain during the procedure and an increase in sensitivity of the processed areas immediately after the treatment. However these effects were recorded in only a few patients and were minimal $[76,77]$.

These findings allow us to conclude that non-ablative fractional laser treatment is an effective method of treatment for atrophic scars (striae, scars, post-acne) and damaged pigmentation, and also that it is applicable to the general improvement of the skin state. At the same time the number of side effects is minimal, and long-term follow-up indicates that the beneficial effects are preserved.

Ablative FP. The use of fractional ablative treatment methods allows a reduction in the time for recovery and in the number of side-effects when compared with the conventional ablative laser resurfacing of the skin, while preserving the same effectiveness of the procedure.

In 2007 Hantash et al. [46] described their first experience of using ablative fractional laser photorejuvenation with a device based on a $\mathrm{CO}_{2}$ laser which creates a network of MTZ damage at a predetermined density and depth. Therefore the ablation and coagulation of the dermis and epidermis including the stratum corneum is constrained within the limits of the MTZs. The study showed that stable collagen remodeling takes place within 3 months of post- 
treatment [40]. By contrast, in the case of non-ablative $\mathrm{FP}, 30$ days are enough for this process.

On evaluating the clinical efficacy of ablative fractional treatment with a $\mathrm{CO}_{2}$ laser $(\lambda=10,600 \mathrm{~nm})$ and an Er:YAG laser $(\lambda=2,940 \mathrm{~nm})$ it was determined that it contributed to an enhancement of the skin state and texture, in particular a reduction of moderate and severe wrinkles, and of dyschromia that was comparable with the results achieved previously with conventional ablative resurfacing [37]. Thus, Karsai et al. [59] showed the wrinkles reduced in depth by $20 \%$ after a single fractional treatment with a $\mathrm{CO}_{2}$ and Er:YAG lasers. Moreover, it was proven with statistical significance that there was a considerable reduction in the severity of wrinkles by 3 months after ablative fractional treatment with erbium lasers with wavelengths of either $2,790 \mathrm{~nm}$ or 2,940 nm [78].

Ablative FP is widely used for the removal of scars of various origins; a $\mathrm{CO}_{2}$ laser treatment is the gold standard for these tasks [79]. Study [80] provides the results of pilot research on the application of a $\mathrm{CO}_{2}$ laser for fractional treatment of post-acne scars in patients with different skin complexions. $87 \%$ of the patients had a considerable stable improvement in the appearance of their scars within 3 months. No short-term or long-term complications connected with hyperpigmentation were registered. Authors [81] showed that the procedure of ablative FP with a $\mathrm{CO}_{2}$ laser considerably improves the state of scars of all degrees of severity. Improvements to scars took place in $26-50 \%$ of their patients, and all the patients showed improvements in the general state of the skin. We should note that neither were there any significant undesirable effects, including hypo- and hyperpigmentation.

Study [82] provides the results of a long-term observation of post-acne scars after ablative FP. By 12 months after the treatment, $12.9 \%$ of the patients showed considerable visual improvements in the state of their scars, while $38.71 \%$ demonstrated moderate improvement. At the same time the clinical effect by 12 months was, as a rule, better than at 3 months, however no statistically significant differences were registered.

The effectiveness of using ablative FP for the treatment of such a state as rhinophyma (chronic disease of the nose skin characterized by an overgrowth of all its elements and disfigurement of the nose) has been investigated [83] and indicated that after 3 months there was a $68.9 \%$ clinical improvement, and no scars, infections or abnormal pigmentation were registered during this period.

It has been shown that conventional laser surfacing results can require a long period for recovery after the procedure and may lead to more serious side effects compared to ablative FP [69]. The undesirable effects of ablative FP compared to non-ablative FP can include greater discomfort during the procedure and immediately afterwards. The discomfort during the first days after the procedure was more pronounced after the treatment with the Er:YAG laser, although, during the follow-up there were more undesirable effects in case of the $\mathrm{CO}_{2}$ laser [59]. Also with both types of lasers all patients had erythema and swelling for at least the first two weeks after the treatment $[80,84]$.

Although many studies have showed the advantages of non-ablative FP through involving minimal side effects and a quicker recovery [85-91], it should be noted that this technology is less effective than ablative resurfacing with $\mathrm{CO}_{2}$ or Er:YAG lasers even if the treatment involves several procedures. Implementation of ablative fractional laser treatment leads to reduced recovery times after the procedure (compared to conventional treatment) as well as to a reduced risk of additional scarring and damaged pigmentation. Ablative FP has shown great potential in the treatment of serious cosmetic defects - scars of various origins and deep wrinkles [92-98].

In conclusion it should be noted that fractional laser photothermolysis is one of the most important discoveries in medical laser technology in the last two decades. Due to the creation of microscopic zones of thermal damage this method of skin treatment leads to safe, quick and complete recovery. The use of this technology for treating various skin diseases and defects, and pathologies of the mucous membranes also serves as a stimulus for its further development.

Study Funding. The work was supported by the Russian Federation state contracts (No.02.740.11.5149 and No.14.740.11.1188) and by Russian Foundation for Basic Research (grant No.1002-01175).

Conflicts of Interest. The authors have no conflicts of interest to disclose.

\section{References}

1. Hsiao F.C., Bock G.N., Eisen D.B. Recent advances in fractional laser resurfacing: new paradigm in optimal parameters and post-treatment wound care. Adv Wound Care (New Rochelle) 2012; 1(5): 207-212, http://dx.doi.org/10.1089/ wound.2011.0323.

2. Baitinger V.F., Paityan K.G. Morphologic and functional characteristics of pathologic skin scars: state of the art. Voprosy rekonstruktivnoy i plasticheskoy khirurgii 2013; 1(44): 28-34.

3. Scar revision - procedures in cosmetic dermatology. Arndt K.A. (editor). Elsevier Inc.; 2006.

4. Goodman G.J., Baron J.A. Postacne scarring a quantitative global scarring grading system. J Cosmet Dermatol 2006; 5(1): 48-52, http://dx.doi.org/10.1111/j.14732165.2006.00222.x.

5. Naein F.F., Soghrati M. Fractional $\mathrm{CO}_{2}$ laser as an effective modality in treatment of striae alba in skin types III and IV. J Res Med Sci 2012; 17(10): 928-933.

6. Zorina A., Zorin V., Cherkasov V. Skin aging and SPRStherapy. Kosmetika i meditsina 2011; 4: 60-68.

7. Tatuzyan E.G., Belovol A.N., Tkachenko S.G. Rational therapy of age-related changes of skin. Dermatologiya $i$ venerologiya 2014; 4(66): 100-108. 
8. Makrantonaki E., Zouboulis C.C. Molecular mechanisms of skin aging: state of the art. Ann $N$ Y Acad Sci 2007; 1119: 40-50, http://dx.doi.org/10.1196/annals. 1404.027

9. Ganceviciene R., Liakou A.I., Theodoridis A., Makrantonaki E., Zouboulis C.C. Skin anti-aging strategies. Dermatoendocrinol 2012; 4(3): 308-319, http://dx.doi. org/10.4161/derm.22804.

10. Molecular mechanisms of skin aging and age-related diseases. Quan T. (editor). CRC Press; 2016, http://dx.doi. org/10.1201/b21370.

11. Geynits A.V., Moskvin S.V. Lazernaya terapiya v kosmetologii $i$ dermatologii [Laser therapy in dermatology and cosmetology]. Moscow-Tver: Izdatel'stvo "Triada"; 2010; $400 \mathrm{p}$.

12. Patrushev A.V., Khairutdinov V.R., Belousova I.E., Samtsov A.V. Clinical and morphological features of elastolytic granulomas. Vestnik dermatologii i venerologii 2014; 4: 58-67.

13. Snarskaya Ye.S. Skin photoaging: current aspects. Vestnik dermatologii i venerologii 2011; 2: 98-103.

14. Kubanov A.A., Zhilova M.B., Kubanova A.A. Skin photoageing: mechanisms of development and particular features of clinical manifestations. Vestnik dermatologii $i$ venerologii 2014; 5: 53-59.

15. Fistarol S.K., Itin P.H. Disorders of pigmentation. J Dtsch Dermatol Ges 2010; 8(3): 187-202, http://dx.doi. org/10.1111/j.1610-0387.2009.07137.x.

16. Kang H.Y., Valerio L., Bahadoran P., Ortonne J.P. The role of topical retinoids in the treatment of pigmentary disorders: an evidence-based review. Am J Clin Dermatol 2009; 10(4): 251-260, http://dx.doi.org/10.2165/00128071200910040-00005.

17. Pandya A.G., Guevara I.L. Disorders of pigmentation. Dermatol Clin 2000; 18(1): 91-98, http://dx.doi.org/10.1016/ s0733-8635(05)70150-9.

18. Shah D., Desai N., Dhanak R. Lasers in facial aesthetics - a review. Adv Hum Biol 2014; 4(3): 1-6.

19. Rinaldi F. Laser: a review. Clin Dermatol 2008; 26(6): 590-601, http://dx.doi.org/10.1016/j.clindermatol.2007.09.014.

20. Karabut M.M., Gladkova N.D., Feldstein F.I., Kiselyova E.B., Fomina Yu.V., Muraev A.A. Use of a fractional laser photothermolysis in clinical practice. Sovremennye tehnologii v medicine 2010; 4: 115-121.

21. Belikov A.V., Pushkareva A.E., Skripnik A.V. Teoreticheskie i eksperimental'nye osnovy lazernoy ablyatsii biomaterialov [Theoretical and experimental bases of laser ablation of biomaterials]. Saint Petersburg: SPbGU ITMO; 2011.

22. Roberts T.L. $3^{\text {rd }}$, Pozner J.N. Lasers, facelifting, and the future. Clin Plast Surg 2000; 27(2): 293-299.

23. Manuskiatti W., Fitzpatrick R.E., Goldman M.P. Longterm effectiveness and side effects of carbon dioxide laser resurfacing for photoaged facial skin. J Am Acad Dermatol 1999; 40(3): 401-411, http://dx.doi.org/10.1016/S01909622(99)70489-5.

24. Schwartz R.J., Burns A.J., Rohrich R.J., Barton F.E., Byrd H.S. Long-term assessment of $\mathrm{CO}_{2}$ facial laser resurfacing: aesthetic results and complications. Plast Reconstr Surg 1999; 103(2): 592-601, http://dx.doi. org/10.1097/00006534-199902000-00037.

25. Weinstein C. Carbon dioxide laser resurfacing: longterm follow up in 2,123 patients. Clin Plast Surg 1998; 25(1): 109-130, http://dx.doi.org/10.1016/s0278-2391(98)90789-3.
26. Berlin A.L., Hussain M., Phelps R., Goldberg D.J. A prospective study of fractional scanned nonsequential carbon dioxide laser resurfacing: a clinical and histopathologic evaluation. Dermatol Surg 2009; 35(2): 222-228, http://dx.doi. org/10.1111/j.1524-4725.2008.34413.x.

27. Bernstein L.J., Kauvar A.N., Grossman M.C., Geronemus R.G. The short- and long-term side effects of carbon dioxide laser resurfacing. Dermatol Surg 1997; 23(7): 519-525, http://dx.doi.org/10.1111/j.1524-4725.1997.tb00677.x.

28. Nanni C.A., Alster T.S. Complications of carbon dioxide laser resurfacing. An evaluation of 500 patients. Dermatol Surg 1998; 24(3): 315-320, http://dx.doi. org/10.1111/j.1524-4725.1998.tb04161.x.

29. Alexiades-Armenakas M.R., Dover J.S., Arndt K.A. The spectrum of laser skin resurfacing: nonablative, fractional, and ablative laser resurfacing. J Am Acad Dermatol 2008; 58(5): 719-740, http://dx.doi.org/10.1016/j.jaad.2008.01.003.

30. Lasers and energy devices for the skin. Goldman M.P., Fitzpatrick R.E., Ross V., Kilmer S.L., Weiss R.A. (editors). CRC Press; 2013, http://dx.doi.org/10.3109/9781841849348.

31. Goldman M.P., Marchell N., Fitzpatrick R.E. Laser skin resurfacing of the face with a combined $\mathrm{CO}_{2} / \mathrm{Er}$ :YAG laser. Dermatol Surg 2000; 26(2): 102-104, http://dx.doi.org/10.1046/ j.1524-4725.2000.98208.x.

32. Goldman M.P., Weiss R.A., Weiss M.A. Intense pulsed light as a nonablative approach to photoaging. Dermatol Surg 2005; 31(9 Pt 2): 1179-1187.

33. Geronemus R.G. Fractional photothermolysis: current and future applications. Lasers Surg Med 2006; 38(3): 169176, http://dx.doi.org/10.1002/lsm.20310.

34. Manstein D., Herron G.S., Sink R.K., Tanner H., Anderson R.R. Fractional photothermolysis: a new concept for cutaneous remodeling using microscopic patterns of thermal injury. Lasers Surg Med 2004; 34(5): 426-438, http://dx.doi. org/10.1002/lsm.20048.

35. Wanner M., Tanzi E.L., Alster T.S. Fractional photothermolysis: treatment of facial and nonfacial cutaneous photodamage with a 1,550-nm erbium-doped fiber laser. Dermatol Surg 2007; 33(1): 23-28, http://dx.doi.org/10.1111/ j.1524-4725.2007.33003.x.

36. Kono T., Chan H.H., Groff W.F., Manstein D., Sakurai H., Takeuchi M., Yamaki T., Soejima K., Nozaki M. Prospective direct comparison study of fractional resurfacing using different fluences and densities for skin rejuvenation in Asians. Lasers Surg Med 2007; 39(4): 311-314, http://dx.doi. org/10.1002/lsm.20484.

37. Tierney E.P., Kouba D.J., Hanke C.W. Review of fractional photothermolysis: treatment indications and efficacy. Dermatol Surg 2009; 35(10): 1445-1461, http://dx.doi. org/10.1111/j.1524-4725.2009.01258.x.

38. Helbig D., Paasch U. Molecular changes during skin aging and wound healing after fractional ablative photothermolysis. Skin Res Technol 2011; 17(1): 119-129, http://dx.doi.org/10.1111/j.1600-0846.2010.00477.x.

39. Arany P.R., Nayak R.S., Hallikerimath S., Limaye A.M., Kale A.D., Kondaiah P. Activation of latent TGF-beta1 by lowpower laser in vitro correlates with increased TGF-beta1 levels in laser-enhanced oral wound healing. Wound Repair Regen 2007; 15(6): 866-874, http://dx.doi.org/10.1111/j.1524475X.2007.00306.X.

40. Hantash B.M., Bedi V.P., Kapadia B., Rahman Z., Jiang K., Tanner H., Chan K.F., Zachary C.B. In vivo histological evaluation of a novel ablative fractional resurfacing 
device. Lasers Surg Med 2007; 39(2): 96-107, http://dx.doi. org/10.1002/lsm.20468.

41. Ravanti L., Kähäri V.M. Matrix metalloproteinases in wound repair (review). Int J Mol Med 2000; 6(4): 391-407, http://dx.doi.org/10.3892/ijmm.6.4.391.

42. Souil E., Capon A., Mordon S., Dinh-Xuan A.T., Polla B.S., Bachelet M. Treatment with $815-\mathrm{nm}$ diode laser induces long-lasting expression of 72-kDa heat shock protein in normal rat skin. Br J Dermatol 2001; 144(2): 260-266, http:// dx.doi.org/10.1046/j.1365-2133.2001.04010.x.

43. Wilmink G.J., Opalenik S.R., Beckham J.T., Abraham A.A., Nanney L.B., Mahadevan-Jansen A., Davidson J.M., Jansen E.D. Molecular imaging-assisted optimization of hsp70 expression during laser-induced thermal preconditioning for wound repair enhancement. J Invest Dermatol 2009; 129(1): 205-216, http://dx.doi.org/10.1038/ jid.2008.175.

44. Atalay M., Oksala N., Lappalainen J., Laaksonen D.E., Sen C.K., Roy S. Heat shock proteins in diabetes and wound healing. Curr Protein Pept Sci 2009; 10(1): 85-95, http://dx.doi. org/10.2174/138920309787315202.

45. Laplante A.F., Moulin V., Auger F.A., Landry J., Li H., Morrow G., Tanguay R.M., Germain L. Expression of heat shock proteins in mouse skin during wound healing. J Histochem Cytochem 1998; 46(11): 1291-1301, http://dx.doi. org/10.1177/002215549804601109.

46. Laubach H.J., Tannous Z., Anderson R.R., Manstein D. Skin responses to fractional photothermolysis. Lasers Surg Med 2006; 38(2): 142-149, http://dx.doi.org/10.1002/lsm.20254.

47. Helbig D., Bodendorf M., Anderegg U., Simon J.C., Paasch U. Human skin explant model to study molecular chances in response to fractional photothermolysis: spatiotemporal expression of HSP70. Medical Laser Application 2010; 25: 173-180.

48. Helbig D., Moebius A., Simon J.C., Paasch U. Nonablative skin rejuvenation devices and the role of heat shock protein 70 : results of a human skin explant model. J Biomed Opt 2010; 15(3): 038002, http://dx.doi. org/10.1117/1.3449736.

49. Kurkinen M., Vaheri A., Roberts P.J., Stenman S. Sequential appearance of fibronectin and collagen in experimental granulation tissue. Lab Invest 1980; 43(1): 47-51.

50. Bailey A.J., Bazin S., Delaunay A. Changes in the nature of the collagen during development and resorption of granulatin tissue. Biochim Biophys Acta 1973; 328(2): 383390, http://dx.doi.org/10.1016/0005-2795(73)90272-9.

51. Liu H., Dang Y., Wang Z., Chai X., Ren Q. Laser induced collagen remodeling: a comparative study in vivo on mouse model. Lasers Surg Med 2008; 40(1): 13-19, http:// dx.doi.org/10.1002/lsm.20587.

52. Orringer J.S., Kang S., Johnson T.M., Karimipour D.J., Hamilton T., Hammerberg C., Voorhees J.J., Fisher G.J. Connective tissue remodeling induced by carbon dioxide laser resurfacing of photodamaged human skin. Arch Dermatol 2004; 140(11): 1326-1332, http://dx.doi.org/10.1001/archderm. 140.11.1326.

53. Gallucci R.M., Lee E.G., Tomasek J.J. IL-6 modulates alpha-smooth muscle actin expression in dermal fibroblasts from IL-6-deficient mice. J Invest Dermatol 2006; 126(3): 561568, http://dx.doi.org/10.1038/sj.jid.5700109.

54. Haisa M., Okochi H., Grotendorst G.R. Elevated levels of PDGF alpha receptors in keloid fibroblasts contribute to an enhanced response to PDGF. J Invest Dermatol 1994; 103(4): 560-563, http://dx.doi.org/10.1111/1523-1747.ep12396856.

55. Kumar S., Millis A.J., Baglioni C. Expression of interleukin 1-inducible genes and production of interleukin 1 by aging human fibroblasts. Proc Natl Acad Sci USA 1992; 89(10): 4683-4687, http://dx.doi.org/10.1073/pnas.89.10.4683.

56. Roth D., Piekarek M., Paulsson M., Christ H., Bloch W., Krieg T., Davidson J.M., Eming S.A. Plasmin modulates vascular endothelial growth factor-A-mediated angiogenesis during wound repair. Am J Pathol 2006; 168(2): 670-684, http://dx.doi.org/10.2353/ajpath.2006.050372.

57. Vaalamo M., Mattila L., Johansson N., Kariniemi A.L., Karjalainen-Lindsberg M.L., Kähäri V.M., Saarialho-Kere U. Distinct populations of stromal cells express collagenase-3 (MMP-13) and collagenase-1 (MMP-1) in chronic ulcers but not in normally healing wounds. J Invest Dermatol 1997; 109(1): 96-101, http://dx.doi.org/10.1111/1523-1747.ep12276722.

58. Hantash B.M., Bedi V.P., Struck S.K., Herron G.S., Chan K.F. Laser-induced transepidermal elimination of dermal content by fractional photothermolysis. J Biomed Opt 2006; 11(4): 041115, http://dx.doi.org/10.1117/1.2241745.

59. Karsai S., Czarnecka A., Jünger M., Raulin C. Ablative fractional lasers $\left(\mathrm{CO}_{2}\right.$ and $\left.\mathrm{Er}: \mathrm{YAG}\right)$ : a randomized controlled double-blind split-face trial of the treatment of peri-orbital rhytides. Lasers Surg Med 2010; 42(2): 160-167, http://dx.doi. org/10.1002/lsm.20879.

60. Chitvanich S., Rerknimitr P., Panchaprateep R., Pongprutthipan M., Asawanonda P. Combination of nonablative fractional photothermolysis and $0.1 \%$ tacrolimus ointment is efficacious for treating idiopathic guttate hypomelanosis. J Dermatolog Treat 2016; 10: 1-5, http:// dx.doi.org/10.3109/09546634.2015.1133883. [Epub ahead of print].

61. Glaich A.S., Rahman Z., Goldberg L.H., Friedman P.M. Fractional resurfacing for the treatment of hypopigmented scars: a pilot study. Dermatol Surg 2007; 33(3): 289-294, http://dx.doi.org/10.1111/j.1524-4725.2007.33058.x.

62. Goldberg D.J., Berlin A.L., Phelps R. Histologic and ultrastructural analysis of melasma after fractional resurfacing. Lasers Surg Med 2008; 40(2): 134-138, http://dx.doi. org/10.1002/lsm.20591.

63. Kouba D.J., Fincher E.F., Moy R.L. Nevus of Ota successfully treated by fractional photothermolysis using a fractionated 1440-nm Nd:YAG laser. Arch Dermatol 2008; 144(2): 156-158, http://dx.doi.org/10.1001/archdermatol. 2007.49.

64. Allemann I.B., Kaufman J. Fractional photothermolysis — an update. Lasers Med Sci 2010; 25(1): 137144, http://dx.doi.org/10.1007/s10103-009-0734-8.

65. Jih M.H., Kimyai-Asadi A. Fractional photothermolysis: a review and update. Semin Cutan Med Surg 2008; 27(1): 6371, http://dx.doi.org/10.1016/j.sder.2008.01.002.

66. Katz T.M., Glaich A.S., Goldberg L.H., Firoz B.F., Dai T., Friedman P.M. Treatment of melasma using fractional photothermolysis: a report of eight cases with long-term followup. Dermatol Surg 2010; 36(8): 1273-1278, http://dx.doi. org/10.1111/j.1524-4725.2010.01621.x.

67. Katz T.M., Goldberg L.H., Firoz B.F., Friedman P.M. Fractional photothermolysis for the treatment of postinflammatory hyperpigmentation. Dermatol Surg 2009; 35(11): 1844-1888, http://dx.doi.org/10.1111/j.15244725.2009.01303.x.

68. Lin J.Y., Warger W.C., Izikson L., Anderson R.R., 
Tannous Z. A prospective, randomized controlled trial on the efficacy of fractional photothermolysis on scar remodeling. Lasers Surg Med 2011; 43(4): 265-272, http://dx.doi. org/10.1002/lsm.21061.

69. Yang Y.J., Lee G.Y. Treatment of striae distensae with nonablative fractional laser versus ablative $\mathrm{CO}_{2}$ fractional laser: a randomized controlled trial. Ann Dermatol 2011; 23(4): 481-489, http://dx.doi.org/10.5021/ad.2011.23.4.481.

70. Bencini P.L., Tourlaki A., Galimberti M., Longo C., Pellacani G., De Giorgi V., Guerriero G. Nonablative fractional photothermolysis for acne scars: clinical and in vivo microscopic documentation of treatment efficacy. Dermatol Ther 2012; 25(5): 463-467, http://dx.doi.org/10.1111/j.15298019.2012.01478.x.

71. Rerknimitr P., Chitvanich S., Pongprutthipan M., Panchaprateep R., Asawanonda P. Non-ablative fractional photothermolysis in treatment of idiopathic guttate hypomelanosis. J Eur Acad Dermatol Venereol 2015; 29(11): 2238-2242, http://dx.doi.org/10.1111/jdv.12763.

72. Karsai S., Fischer T., Pohl L., Schmitt L., Buhck H., Jünger M., Raulin C. Is non-ablative 1550-nm fractional photothermolysis an effective modality to treat melasma? Results from a prospective controlled single-blinded trial in 51 patients. J Eur Acad Dermatol Venereol 2012; 26(4): 470-476, http://dx.doi.org/10.1111/j.1468-3083.2011.04100.x.

73. Wanitphakdeedecha R., Keoprasom N., Eimpunth S., Manuskiatti W. The efficacy in melasma treatment using a $1410 \mathrm{~nm}$ fractional photothermolysis laser. J Eur Acad Dermatol Venereol 2014; 28(3): 293-297, http://dx.doi. org/10.1111/jdv.12100.

74. Liu Y., Zeng W., Hu D., Jha S., Ge Q., Geng S., Xiao S., Hu G., Wang $X$. The long-term effect of $1550 \mathrm{~nm}$ erbium: glass fractional laser in acne vulgaris. Lasers Med Sci 2016; 31(3): 453-457, http://dx.doi.org/10.1007/s10103-016-1871-5.

75. Dahan S., Lagarde J.M., Turlier V., Courrech L., Mordon S. Treatment of neck lines and forehead rhytids with a nonablative 1540-nm Er: glass laser: a controlled clinical study combined with the measurement of the thickness and the mechanical properties of the skin. Dermatol Surg 2004; 30(6): 872-880, http://dx.doi.org/10.1111/j.1524-4725.2004.30256.x.

76. Kim B.J., Lee D.H., Kim M.N., Song K.Y., Cho W.I., Lee C.K., Kim J.Y., Kwon O.S. Fractional photothermolysis for the treatment of striae distensae in Asian skin. Am J Clin Dermatol 2008; 9(1): 33-37, http://dx.doi. org/10.2165/00128071-200809010-00003.

77. Lee S.M., Kim M.S., Kim Y.J., Won C.H., Lee M.W., Choi J.H., Moon K.C., Chang S.E. Adverse events of nonablative fractional laser photothermolysis: a retrospective study of 856 treatments in 362 patients. J Dermatolog Treat 2014; 25(4): 304-307, http://dx.doi.org/10.3109/09546634.2013.777151.

78. Dierickx C.C., Khatri K.A., Tannous Z.S., Childs J.J., Cohen R.H., Erofeev A., Tabatadze D., Yaroslavsky I.V., Altshuler G.B. Micro-fractional ablative skin resurfacing with two novel erbium laser systems. Lasers Surg Med 2008; 40(2): 113-123, http://dx.doi.org/10.1002/lsm.20601.

79. Lloyd J., Tanghetti E. Comparison of Affirm 1320/1440 nm versus $1320 \mathrm{~nm}$ for the treatment of acne scars - clinical and histologic study. Lasers Surg Med 2008; 66: 27.

80. Walgrave S.E., Ortiz A.E., MacFalls H.T., Elkeeb L., Truitt A.K., Tournas J.A., Zelickson B.D., Zachary C.B. Evaluation of a novel fractional resurfacing device for treatment of acne scarring. Lasers Surg Med 2009; 41(2): 122-127, http://dx.doi.org/10.1002/lsm.20725.
81. Chapas A.M., Brightman L., Sukal S., Hale E., Daniel D., Bernstein L.J., Geronemus R.G. Successful treatment of acneiform scarring with $\mathrm{CO}_{2}$ ablative fractional resurfacing. Lasers Surg Med 2008; 40(6): 381-386, http:// dx.doi.org/10.1002/lsm.20659.

82. Qian H., Lu Z., Ding H., Yan S., Xiang L., Gold M.H. Treatment of acne scarring with fractional $\mathrm{CO}_{2}$ laser. $J$ Cosmet Laser Ther 2012; 14(4): 162-165, http://dx.doi.org/10.3109/14 764172.2012.699679.

83. Singh S., Peterson J.D., Friedman P.M. Management of mild to moderate rhinophyma using ablative fractional photothermolysis. Dermatol Surg 2013; 39(7): 1110-1113, http://dx.doi.org/10.1111/dsu.12222.

84. Kim S. Clinical trial of a pinpoint irradiation technique with the $\mathrm{CO}_{2}$ laser for the treatment of atrophic acne scars. J Cosmet Laser Ther 2008; 10(3): 177-180, http://dx.doi. org/10.1080/14764170801930080.

85. Aldahan A.S., Shah V.V., Mlacker S., Samarkandy S., Alsaidan M., Nouri K. Laser and light treatments for striae distensae: a comprehensive review of the literature. Am J Clin Dermatol 2016; 17(3): 239-256, http://dx.doi.org/10.1007/ s40257-016-0182-8.

86. Alexis A.F., Coley M.K., Nijhawan R.I., Luke J.D., Shah S.K., Argobi Y.A., Nodzenski M., Veledar E., Alam M. Nonablative fractional laser resurfacing for acne scarring in patients with fitzpatrick skin phototypes IV-VI. Dermatol Surg 2016; 42(3): 392-402, http://dx.doi.org/10.1097/DSS. 0000000000000640.

87. Augustyniak A., Rotsztejn H. Fractional nonablative laser treatment $1410 \mathrm{~nm}$ for periorbital wrinkles reviscometrical and clinical evaluation. J Cosmet Laser Ther 2016; 10: 1-14, http://dx.doi.org/10.3109/14764172.2016.115 7370 .

88. Cachafeiro T., Escobar G., Maldonado G., Cestari T., Corleta O. Comparison of nonablative fractional erbium laser $1,340 \mathrm{~nm}$ and microneedling for the treatment of atrophic acne scars: a randomized clinical trial. Dermatol Surg 2016; 42(2): 232-241, http://dx.doi.org/10.1097/DSS. 0000000000000597.

89. Finney R., Torbeck R., Saedi N. Non-ablative fractional resurfacing in the treatment of scar contracture. Lasers Surg Med 2016; 48(2): 170-173, http://dx.doi.org/10.1002/ Ism.22400.

90. Friedmann D.P., Tzu J.E., Kauvar A.N., Goldman M.P. Treatment of facial photodamage and rhytides using a novel $1,565 \mathrm{~nm}$ non-ablative fractional erbium-doped fiber laser. Lasers Surg Med 2016; 48(2): 174-180, http://dx.doi. org/10.1002/lsm.22461.

91. Taudorf E.H., Danielsen P.L., Paulsen I.F., Togsverd-Bo K., Dierickx C., Paasch U., Haedersdal M. Nonablative fractional laser provides long-term improvement of mature burn scars - a randomized controlled trial with histological assessment. Lasers Surg Med 2015; 47(2): $141-$ 147, http://dx.doi.org/10.1002/lsm.22289.

92. Azzam O.A., Bassiouny D.A., El-Hawary M.S., El Maadawi Z.M., Sobhi R.M., El-Mesidy M.S. Treatment of hypertrophic scars and keloids by fractional carbon dioxide laser: a clinical, histological, and immunohistochemical study. Lasers Med Sci 2016; 31(1): 9-18, http://dx.doi.org/10.1007/ s10103-015-1824-4.

93. Banihashemi M., Nahidi Y., Maleki M., Esmaily $H_{\text {., }}$ Moghimi H.R. Efficacy of fractional $\mathrm{CO}_{2}$ laser in treatment of atrophic scar of cutaneous leishmaniasis. Lasers Med Sci 
2016; 31(4): 733-739, http://dx.doi.org/10.1007/s10103-0161919-6.

94. Firooz A., Rajabi-Estarabadi A., Nassiri-Kashani M.H. Treatment of atrophic facial acne scars with fractional Er:YAG laser in skin phototype III-IV: a pilot study. J Cosmet Laser Ther 2016, http://dx.doi.org/10.3109/14764172.2016.1157354. [Epub ahead of print].

95. Gan S.D., Hsu S.H., Chuang G., Konnikov N., Liang C.A. Ablative fractional laser therapy for the treatment of actinic keratosis: a split-face study. J Am Acad Dermatol 2016; 74(2): 387-389, http://dx.doi.org/10.1016/j.jaad.2015.08.035.

96. Kositratna G., Hibert M.L., Jaspan M., Welford D., Manstein D. Effects of deviation from focal plane on lesion geometry for ablative fractional photothermolysis. Lasers Surg Med 2016, http://dx.doi.org/10.1002/lsm.22481. [Epub ahead of print].

97. Lee D., Park E.S., Tak M.S., Nam S.M. The effectiveness of ablative fractional carbon dioxide laser with autologous platelet rich plasma combined resurfacing for hypertrophic scar of the shoulder. Arch Aesthetic Plast Surg 2016; 22(1): 40, http://dx.doi.org/10.14730/aaps.2016.22.1.40.

98. Schoenewolf N.L., Hafner J., Dummer R., Allemann I.B. Laser treatment of solar lentigines on dorsum of hands: QS Ruby laser versus ablative $\mathrm{CO}_{2}$ fractional laser - a randomized controlled trial. Eur J Dermatol 2015; 25(2): 122126, http://dx.doi.org/10.1684/ejd.2014.2513. 